\title{
Risk of coeliac disease in children of patients and effect of HLA genotype
}

\author{
N. R. DENNIS ${ }^{1}$ AND C. R. STOKES ${ }^{2}$ \\ From M.R.C. Clinical Genetics Unit and Department of Immunology, Institute of Child Health, London WCI \\ NIEH
}

SUMMARY Among 73 offspring of parents with coeliac disease, 4 were affected, including 1 in whom the diagnosis was made as a result of the study. The coeliac parents of all 4 were HLA-B8 positive, but $\vec{T}$ 1 affected child had failed to inherit his affected parent's B8 antigen. The findings are consistent with the hypothesis that an allele affecting liability to coeliac disease is in linkage disequilibrium with HLAB8.

Coeliac disease is known to be familial (Carter et al., 1959; MacDonald et al., 1965; David and Ajdukiewicz, 1975), and to be associated in the population with the antigen HLA-B8 (Falchuk et al., 1972). HLA-B8 probably acts as a marker for a closely linked gene affecting liability and in linkage disequilibrium with it (Harms et al., 1974), though it has been claimed that the HLA-B8 allele itself affects liability (Nelson et al., 1975).

The present study was planned to add to the information on the risk to the children of patients, and to see to what extent this risk is affected by the HLA-B gene inherited from the coeliac parent.

\section{Patients and methods}

Forty index patients aged 25 to 65 years were selected because they had at least one child over the age of 1 year. In 27 patients (childhood onset), 24 females and 3 males, the onset of symptoms was before the age of 12 years. Twenty of these patients had a welldocumented response to a gluten-free diet during childhood. Eighteen of them had had a jejunal biopsy, and 1 a duodenoscopy which confirmed the diagnosis. For the 8 patients with no jejunal biopsy confirmation, records from The Hospital for Sick Children, Great Ormond Street, were available, showing a typical presentation and response to treatment during childhood. One patient had relapsed in adolescence and had been put back on a gluten-free diet without a

'Present address: Division of Human Genetics, Children's Hospital, Buffalo, New York 14222, U.S.A.

${ }^{2}$ Present address: Department of Animal Husbandry, University of Bristol, Langford, near Bristol.

Received for publication 10 May 1977

jejunal biopsy, and three others were shown to have low levels of iron or folic acid while on a normal diet. It is, therefore, unlikely that there was a significant $\vec{\varphi}$ number who did not have coeliac disease among these $\infty$ index patients.

In 13 patients (adult onset), 9 female and 4 male, the onset of the disease was between 21 and 57 years, with no history of childhood symptoms. All the adult $\bar{\partial}$ onset patients had had a jejunal biopsy which confirmed the diagnosis.

The index patients were visited at home and $\overrightarrow{\vec{O}}$ questioned about possible symptoms of coeliac disease $\overline{3}$ in their children. The children were weighed and their heights measured, Blood was taken from parents and children for HLA typing, haemoglobin, serum iron, and serum and red cell folate estimations. HLA typing was omitted in some of the relatively uninfor- $\bar{\sigma}$ mative one child families.

Serum iron and serum and red cell folate $\delta$ estimations were done by routine techniques in use in the haematology laboratories at The Hospital for Sick 의 Children. Twenty-three HLA antigens were tested for using 108 antisera on Ficol-Triosil separated lymphocytes by a standard microcytotoxicity assay.

\section{Results}

The 27 childhood onset index patients had 51 children, aged 1 to 24 years, of whom 2 had typical childhood 0 coeliac disease responding to a gluten-free diet and $\overparen{D}$ confirmed by an abnormal jejunal biopsy. In addition, $\stackrel{\odot}{+}$ 12 children were classed as 'suspected'. Three of these $\underline{T}$ had already had a jejunal biopsy because of symptoms suggesting coeliac disease, and all had been normal 
while on a normal diet. The other 9 were selected because of low height or weight for their age (3), a history of gastrointestinal symptoms (6), or low serum iron or folic acid levels (6). Serum iron levels below 80 $\mu \mathrm{g} / 100 \mathrm{ml}$, serum folate levels below $5 \mathrm{ng} / \mathrm{ml}$, and red cell folate levels below $150 \mathrm{ng} / \mathrm{ml}$ were considered low, but the children were assessed individually and usually more than a single low value was required to place them in the suspected group. Jejunal biopsies were performed in 5 of these suspected children and all were normal. Jejunal biopsies were not done on the other 4 children, in 3 because the parents did not consent and in 1 because of technical difficulties.

The 13 adult onset index patients had 22 children aged 3 to 40 years, of whom 1 had childhood coeliac disease with a typical clinical course and response to a gluten-free diet, with 3 relapses on reversion to a normal diet. She had never had a jejunal biopsy, however. Two of the 22 children were classed as suspected; both had a history suggesting childhood coeliac disease, 1 had already had a normal jejunal biopsy while on a normal diet; in the other, jejunal biopsy was performed and showed subtotal villous atrophy. This child was then counted as affected, making 4 affected in all.

HLA typing was done in 25 of the childhood onset index patients. Twenty-one possessed the B8 antigen, one was known from family studies to be homozygous $\mathrm{B} 8 / \mathrm{B} 8$, and 4 could have been $\mathrm{B} 8 / \mathrm{B} 8$ or $\mathrm{B} 8 / \mathrm{By}(\mathrm{y}=$ blank allele). The distribution of the other HLA-B antigens was unremarkable except for an insignificant increase in B 12 (8/25 patients, 6 being B8/B 12).

All 7 of the adult onset index patients typed possessed the $\mathrm{B} 8$ antigen; one was $\mathrm{B} 8 / \mathrm{B} 8$ or $\mathrm{B} 8 / \mathrm{By}$, and 3 were B8/B12. Among the whole series of 40 index patients, 32 were typed and 28 possessed the B8 antigen.

To test the hypothesis that the B8 antigen carried by an affected parent acts as a marker for increased liability, the numbers of unaffected, suspected, and affected children are listed in Table 1 according to whether they inherited or failed to inherit the B8 antigen from a parent heterozygous for B8. The children of parents who were $\mathrm{B8} / \mathrm{B8}$ or $\mathrm{B} 8 / \mathrm{By}$ (possibly homozygous) are listed separately, since such children are obligatory carriers of a B8 allele if the parent is homozygous. Untyped children and those whose parents were HLA-B8 negative are listed together.

The 4 affected children were from different families. Among the 11 children of affected parents homozygous or possibly homozygous for B8, 2 were affected. Among the children of affected parents heterozygous for B8, 18 inherited and 26 failed to inherit the B8 antigen. There was 1 affected child in each group. Thus, in this small series, no difference in liability associated with the possession of HLA-B8 could be shown in the children. The proportion of suspected children also showed no significant difference between those who had and those who had not inherited B8 from an affected parent.

\section{Discussion}

The recurrence risk of overt coeliac disease found in these children of patients, 3 in 73 , is of the same order as that reported in sibs of patients (Carter et al., 1959), but lower than that found in a series of 140 children from 79 index patients, 10 of whom were affected (T. J. David and A. B. Ajdukiewicz, 1975, personal communication). Both of the studies referred to counted only overt coeliac disease already diagnosed at the time of the study. Other investigators have found that a proportion of first degree relatives, though asymptomatic, have the histological features of coeliac disease on jejunal biopsy (Mylotte et al., 1974;

Table 1 Summary of findings in 73 children

\begin{tabular}{|c|c|c|c|c|c|}
\hline & \multicolumn{2}{|c|}{$\begin{array}{l}\text { Affected parent } \\
\text { heterozygous B8 }\end{array}$} & \multirow{2}{*}{$\begin{array}{l}\text { Affected parent } \\
\text { definitely or possibly } \\
\text { homozygous } B 8\end{array}$} & \multirow{2}{*}{$\begin{array}{l}\text { Affected parent } \\
\text { B8 negative or } \\
\text { child not typed }\end{array}$} & \multirow[t]{2}{*}{ Total } \\
\hline & $\begin{array}{l}\text { Child } \\
\text { B8 pos }\end{array}$ & $\begin{array}{l}\text { Child } \\
\text { B8 neg }\end{array}$ & & & \\
\hline \multicolumn{6}{|c|}{ Childhood onset index patients } \\
\hline Unaffected & 6 & 16 & 4 & 11 & 37 \\
\hline Suspected & $4(3)$ & $5(5)$ & $3(-)$ & - & 12 \\
\hline Affected & 1 & - & 1 & - & 2 \\
\hline Total & 11 & 21 & 8 & 11 & 51 \\
\hline \multicolumn{6}{|c|}{ Adult onset index patients } \\
\hline Unaffected & 6 & 4 & 2 & 7 & 19 \\
\hline Suspected & $1(1)$ & - & - & - & 1 \\
\hline Affected & - & 1 & 1 & - & 2 \\
\hline $\begin{array}{l}\text { Total } \\
\text { Whole series }\end{array}$ & 7 & 5 & 3 & 7 & 22 \\
\hline Unaffected & 12 & 20 & 6 & 18 & 56 \\
\hline Suspected & $5(4)$ & $5(5)$ & $3(-)$ & - & 13 \\
\hline Affected & 1 & 1 & 2 & - & 4 \\
\hline Total & 18 & 26 & 11 & 18 & 73 \\
\hline
\end{tabular}


Stokes et al., 1976). Such relatives are usually regarded as having latent or subclinical coeliac disease. Thus the proportion of sibs, parents, and children of patients showing jejunal villous atrophy appears to be about $10 \%$. For example, Stokes et al. (1976) found, among the 62 children of 24 index patients, 8 affected-approximately double the recurrence risk that we found. The difference is probably related to the fact that the jejunal biopsy rate in their study was $57 / 62$, compared with $12 / 73$ in ours. Many of the 'new' coeliacs had, in retrospect, low levels of haemoglobin, serum folate, albumin, or iron, but reliance on such measurements in screening relatives for biopsy appears in the light of the present study to be misplaced.

It seems likely that there are patients who later prove to have coeliac disease, in whom the jejunal biopsy appearance while on a free diet has been normal or only mildly abnormal (Dellipiani, 1975; McConnell and Whitwell, 1975). Some of the normal biopsies obtained in our suspected children may fall into this category, and some of them may later develop the condition.

The low biopsy rate in our study, and the probable inadequacy of the jejunal biopsy in diagnosing normality, therefore, combine to make our estimate of the recurrence risk a minimum one.

We identified 1 family in which HLA-B8 segregated separately from coeliac disease. A comparison of our HLA results in offspring with those of the Birmingham authors is shown in Table 2, ignoring for this purpose our distinction between heterozygous and homozygous B8 positive parents. Overall, 3 out of 12 affected offspring born to HLA-B8 positive parents were $B 8$ negative. This reinforces the hypothesis that the HLA-B8 allele makes no direct contribution to liability but acts as a marker for a neighbouring coeliac disease susceptibility gene in linkage disequilibrium with it.

Although our data suggest that the risk to children of homozygous B8 positive affected parents may be higher than to children of B8 heterozygotes, the numbers are small, and this could easily have been a chance finding. If confirmed, it would be difficult to explain on the basis of a B8-linked susceptibility gene.

Other observations which argue against a direct effect of the B8 allele on susceptibility are (1) where both parents are $\mathrm{B} 8$ positive the risk of coeliac disease

Table 2 Comparison of $H L A$ findings in offspring of $H L A-B 8$ positive parents in Birmingham and present series

\begin{tabular}{lllll}
\hline & $\begin{array}{l}\text { B8 positive } \\
\text { Index patients }\end{array}$ & Children & B8 pos & B8 neg \\
\hline $\begin{array}{l}\text { Birmingham } \\
\text { (Stokes et al., 1976) }\end{array}$ & 24 & 48 & $24(6)$ & $24(2)$ \\
\begin{tabular}{l} 
Present study \\
\hline
\end{tabular} & 28 & 55 & $28(3)$ & $27(1)$ \\
\hline
\end{tabular}

Figures in parentheses are number affected. in the children is not detectably different from that in families where only one parent is B8 positive (the families having been ascertained by having at least one affected member) (Stokes et al., 1976), and (2) the association between the HLA-DW3 allele and coeliac disease is stronger than that shown for HLA-B8 (Keuning et al., 1976).

We thank Dr J. T. Harries and his colleagues of The Hospital for Sick Children, Great Ormond Street, for performing jejunal biopsies on the children, Dr A. M. Dawson and Dr Parveen Kumar and their colleagues at St Bartholomew's Hospital for permission to contact their patients and for performing jejunal biopsies on some of the adult patients, Professor R. M. Hardisty and Dr F. G. Hill of the Haematology Department, The Hospital for Sick Children, for the haematological investigations, Professor C. O. Carter and Professor J. F. Soothill for valuable discussions, and the patients and their families, and their general practitioners, for their co-operation.

N.R.D. thanks the Dr Henry C. and Bertha H. Buswell Research Foundation, School of Medicine, State University of New York at Buffalo, for the award of a Buswell Fellowship during the preparation of this paper.

\section{References}

Carter, C. O., Sheldon, W., and Walker, C. (1959). The Inheritance of coeliac disease. Annals of Human Genetics, 23, 266-278.

David, T. J., and Ajdukiewicz, A. B. (1975). A family study of coeliac disease. Journal of Medical Genetics, 12, 79-82.

Dellipiani, A. W. (1975). Small intestinal histology in coeliac disease. Lancet, 2, 550,

Falchuk, Z. M., Rogentine, G. N., and Strober, W. (1972). Predominance of histocompatibility antigen HL-A8 in patients with gluten-sensitive enteropathy. Journal of Clinical Investigation, 51, 1602-1605.

Harms, K., Granditsch, G., Rossipal, E., Ludwig, H., Polymenidis, Z., Scholz, S., Wank, R., and Albert, E. I. (1974). HL-A in patients with coeliac disease and their families. In Coeliac Disease, Proceedings of the Second International Coeliac Symposium, pp. 215-226. Ed. by W. T. J. M. Hekkens and A. S. Peña. H. E. Stenfert-Kroese, Leiden.

Keuning, J. J., Peña, A. S., van Leeuwen, A., van Hoof, J. P., and van Rood, J. J. (1976). HLA-DW3 associated with coeliac disease. Lancet, 1, 506-508.

McConnell, R. B., and Whitwell, F. (1975). Small intestinal histology in coeliac disease. Lancet, 2, 418.

MacDonald, W. C., Dobbins, W. O., and Rubin, C. E. (1965). Studies of the familial nature of celiac sprue using biopsy of the small intestine. New England Journal of Medicine, 272, 448-456.

Mylotte, M., Egan-Mitchell, B., Fottrell, P. F., McNicholl, B., and McCarthy, C. F. (1974). Family studies in coeliac disease. Lancet, 2, 162-164.

Nelson, I. L., Falchuk, Z. M., Kasarda, D., and Strober, W. (1975). Gluten sensitive enteropathy: correlation of organ-culture behavior with HL-A status. Clinical Research, 23, 254.

Stokes, P. L., Ferguson, R., Holmes, G. K. T., and Cooke, W. T. (1976). Familial aspects of coeliac disease. Quarterly Journal of Medicine, 43, 567-582.

Requests for reprints to Dr N. R. Dennis, Division of Human Genetics, Children's Hospital, 86 Hodge Avenue, Buffalo, New York 14222, U.S.A. 